\title{
USE OF SEED $^{+\circledast}$ AND CROP ${ }^{+\oplus}$ BIOESTIMULANTS ON THE QUALITY OF TOMATO FRUITS UNDER WATER STRESS ${ }^{1}$
}

\author{
MARIANE PERIPOLLI ${ }^{2 *}$, ANTONIO CARLOS FERREIRA DA SILVA ${ }^{2}$, SYLVIO HENRIQUE BIDEL DORNELLES $^{2}$, \\ DANIE MARTINI SANCHOTENE ${ }^{3}$, VINICIUS SEVERO TRIVISIOL ${ }^{4}$
}

\begin{abstract}
Accelerated biotic and abiotic stresses have diminished the quality and yield of agricultural products. Thus, the use of biostimulants comes with the proposal of reducing the stresses experienced by plants and, consequently, reducing agricultural losses. The objective of this work was to evaluate the effects of Seed ${ }^{+\circledR}$ and Crop ${ }^{+\otimes}$ biostimulants on tomato fruits, cultivar Santa Cruz Kada, under water stress. The experiment was conducted in a greenhouse. A completely randomized experimental design was used, in a 2 × 2 × 6 three-factor scheme, with the following factors: application time (flowering and fruiting), soil water conditions $(50 \%$ and $100 \%$ of soil water retention capacity) and biostimulants (without treatment; Seed ${ }^{+\circledR}$; Seed $^{+\circledR}+$ Crop $^{+\circledR} 1 \mathrm{x}$ the

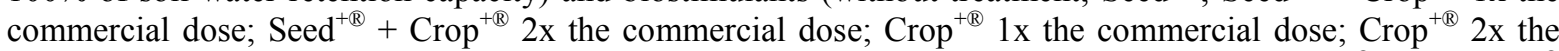
commercial dose). Under water deficit conditions, the fruits of plants treated with Seed ${ }^{+\circledR}$ and Crop $^{+\circledR}$ biostimulants had higher values of $\mathrm{pH}$, total soluble solids and titratable acidity compared to plants that did not receive biostimulants. Seed ${ }^{+\circledast}$ and Crop $^{+\circledast}$ biostimulants maintain the quality of tomato fruits until 18 days after harvest.
\end{abstract}

Keywords: Water condition. Time of application. Post-harvest. Solanum lycopersicum L.

\section{USO DE BIOESTIMULANTES NA QUALIDADE DE FRUTOS DE TOMATEIRO SOB ESTRESSE HÍDRICO}

RESUMO - Os acelerados estresses bióticos e abióticos têm diminuído a qualidade e produtividade dos produtos agrícolas. Assim, o uso de bioestimulantes vêm com a proposta de redução dos estresses sofridos pelas plantas, e consequentemente, reduzir as perdas agrícolas. O objetivo deste trabalho foi avaliar os efeitos do bioestimulantes Seed ${ }^{+\circledR}$ e Crop $^{+\circledast}$ na qualidade de frutos de tomateiro, cultivar Santa Cruz Kada, induzidas ao estresse hídrico. O experimento foi conduzido em casa de vegetação. Utilizou-se o delineamento experimental inteiramente casualizado, em esquema trifatorial $2 \times 2 \times 6$, sendo os fatores: época de aplicação (florescimento e frutificação), condições hídricas do solo (50\% e 100\% da capacidade de retenção de água no

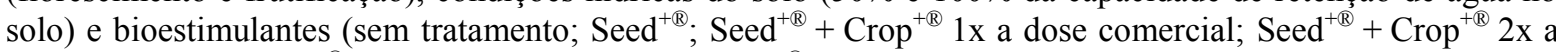
dose comercial; $\operatorname{Crop}^{+\circledast} 1 \mathrm{x}$ a dose comercial; $+\operatorname{Crop}^{+\circledast} 2 \mathrm{x}$ a dose comercial). Em condições de deficiência hídrica, os frutos das plantas tratadas com os bioestimulantes Seed $^{+\circledR}$ e Crop ${ }^{+\circledR}$ tiveram maiores valores de $\mathrm{pH}$, sólidos solúveis totais e acidez titulável em comparação com as plantas que não receberam os bioestimulantes Os bioestimulantes Seed ${ }^{+\circledR}$ e Crop $^{+\circledR}$ mantêm a qualidade de frutos de tomateiro até 18 dias após a colheita.

Palavras-chave: Condição hídrica. Época de aplicação. Pós-colheita. Solanum lycopersicum L.

\footnotetext{
${ }^{*}$ Corresponding author

${ }^{1}$ Received for publication in $06 / 18 / 2019$; accepted in $12 / 03 / 2019$.

Paper extracted from the dissertation of the first author.

${ }^{2}$ Department of Biology, Universidade Federal de Santa Maria, Santa Maria, RS, Brazil; mperipolli@gmail.com - ORCID: 0000-00022147-9458, acfsilva2@uol.com.br - ORCID: 0000-0002-1050-1656, sylviobidel@gmail.com - ORCID: 0000-0002-1097-6176.

${ }^{3}$ Department of Agriculture, Universidade Regional Integrada do Alto Uruguai e das Missões, Santiago, RS, Brazil; danie.sanchotene@biomonte.com-ORCID: 0000-0001-5101-6625.

${ }^{4}$ Department of Phytotechnics, Universidade Federal de Santa Maria, Santa Maria, RS, Brazil; vinicius_trivisiol@hotmail.com - ORCID: 0000-0003-1108-6471.
} 


\section{INTRODUCTION}

Tomato (Solanum lycopersicum L.) cultivation stands out as an important economic and social activity, and it is the second most produced vegetable in the world (NASIR et al., 2015; STAJCIC' et al., 2015). It is one of the most consumed vegetables, both fresh (table tomato) and processed (industrial tomato) (BRITO JUNIOR, 2012). In 2018, Brazil became the world's eighth largest producer of tomatoes, with production of 4.5 million tons (IBGE, 2019).

Tomato crop is directly influenced by endogenous and exogenous factors. Water stress is one of the stresses that most interfere with the plant's morphophysiological processes, negatively affecting biochemical and metabolic processes (MOZDZEN et al., 2015). Currently, water deficit is one of the main factors threatening food safety, so new research is emerging to reverse the effects caused by this stress and consequently maintain high levels of yield without affecting fruit quality (ALBACETE; MARTÍNEZ-ANDÚJAR; PÉREZALFOCEA 2014; GOLLDACK et al., 2014). According to Vieites, Daiuto and Fumes (2012), water stress has a direct influence on fruit quality, reducing mass, $\mathrm{pH}$ and soluble solids, and increasing titratable acidity, thus making the fruit less palatable.

In an attempt to mitigate the damage caused by water stress, the use of biostimulants is an alternative as they can contribute to the improvement of soil physicochemical properties, absorption, translocation and use of nutrients by plants, as well as increased resistance to stresses (CALVO; NELSON; KLOEPPER, 2014; DU JARDIN, 2015). These biostimulants are based on extracts of seaweed, Ascophyllum nodosum (L.), which generates an improvement in plant growth, yield, quality and tolerance to biotic and abiotic stresses (DU JARDIN, 2015; VAN OOSTEN et al., 2017). This occurs because it favors the signaling in plants for the production of elicitor or osmoprotective substances, for having high levels of glycine-betaine (GB) and proline (BULGARI et al., 2015).

Tomato can be a climacteric fruit, with high metabolic activity in the post-harvest period, which causes physiological and biochemical transformations in the fruit and leads to a high rate of postharvest losses (FERREIRA et al., 2012). In this context, although visual and physical aspects are the main factors influencing the decision to purchase made by consumers, parameters related to the nutritional quality of fruits are relevant, such as mass loss, $\mathrm{pH}$, titratable acidity, soluble solids, color, and soluble solids/titratable acidity ratio (VIEITES; DAIUTO; FUMES, 2012).

Although the beneficial effects of the application of biostimulants have been confirmed in several crops, further research is needed to better evaluate their effects on tomato fruit quality. As the biostimulants Seed $^{+\circledR}$, in seed treatment, and Crop ${ }^{+\circledR}$, during the reproductive stage, act as protectors of tomato plants against stress caused by water deficit, the present study aimed to evaluate the effects of Seed $^{+\circledR}$ and Crop ${ }^{+\circledR}$ biostimulants on the quality of tomato fruits, cultivar Santa Cruz Kada, after plants were subjected to water stress.

\section{MATERIAL AND METHODS}

The experiment was conducted in a greenhouse $(50 \mathrm{~m} \times 12 \mathrm{~m})$, at the Experimental Station in Boca do Monte District (29³9.059' S and $\left.53^{\circ} 57.413^{\prime} \mathrm{W}\right)$ in the municipality of Santa Maria, Rio Grande do Sul, RS, Brazil, from February to July 2018. According to Köppen's classification, the climate of the region is Cfa, subtropical humid, with hot summers and with no defined dry season (HELDWEIN; BURIOL; STRECK, 2009).

The soil is classified as Argissolo Vermelho Distrófico arênico (Ultisol). These soils have base saturation $<50 \%$ in most of the first $100 \mathrm{~cm}$ of the $\mathrm{AB}$ horizon. According to the Agricultural Zoning MAPA, the soil is considered type 2; its textural class (SBCS) is Sandy Loam, with $60.6 \%$ sand, $22.9 \%$ silt and $16.6 \%$ clay, according to the physical analysis report of the Soil Physics Laboratory UFSM.

A completely randomized experimental design in a $2 \times 2 \times 6$ three-factor scheme, with five replicates, was used. The first factor consisted of soil water conditions $(50 \%$ and $100 \%$ of soil water retention capacity (WRC), the second was represented by the application times (early flowering and early fruiting), and the third comprised the biostimulants (without treatment; Seed ${ }^{+\circledR} ;$ Seed $^{+\circledR}+$ Crop $^{+\circledR} 1 \mathrm{x}$ commercial dose; Seed $^{+\circledR}+$ Crop $^{+\circledR} 2 \mathrm{x}$ commercial dose; Crop $^{+\circledast} 1 \mathrm{x}$ commercial dose; + Crop $^{+\circledR} 2 \mathrm{x}$ commercial dose).

Soil WRC was determined by drying the soil until reaching constant mass (oven at $70{ }^{\circ} \mathrm{C}$ ). Subsequently, a known mass of dry soil was placed in a pot perforated at the base for draining excess water. The pot was irrigated until soil saturation occurred and, subsequently, drained until the moment it reached constant mass. Soil water conditions ( $50 \%$ and $100 \% \mathrm{WRC}$ ) were determined using the following adapted formulas (SCHWAB, 2011):

PM50\% $=($ PMWRC - PMdry $) \times 0.5+$ PMdry

PM100\% $=($ PMWRC - PMdry $) \times 1.0+$ PMdry

Where: $\mathrm{PMn} \%$ is the pot mass for each of the treatments; PMWRC is the pot mass at water retention capacity $(100 \%$ of soil WRC); PMdry corresponds to the mass of the pot filled with dry soil.

Sowing was performed on polystyrene foam trays with 200 cells filled with Mecplant ${ }^{\mathbb{R}}$ substrate, 
kept in a greenhouse, with floating irrigation. Two floating systems were constructed, one of which received the application of the biostimulant $\operatorname{Seed}^{+\circledR}$ at the dose of $100 \mathrm{~mL} 100 \mathrm{~L}^{-1}$ of water (dose defined by the directions for use), applied as seed treatment, next to the floating system. The second floating system received only water. The seedlings remained in this system until the moment of transplantation.

After 30 days from sowing, the seedlings were transplanted to 9-L black polypropylene pots, filled with $8.5 \mathrm{~kg}$ of soil, sieved, homogenized and with acidity corrected according to soil analysis, each pot representing one experimental unit. Fertilization of the experimental units was based on soil analysis according to the recommendations of the Official Soil Analysis Laboratory Network (Rede Oficial de Laboratório de Análise de Solos ROLAS) for tomato crop.

These amounts of water were supplied daily by the weighing method, using a digital highprecision electronic scale (ACS System brand) with capacity for $40 \mathrm{~kg}$ and accuracy of $5 \mathrm{~g}$. Water was added until reaching the total predetermined mass (pot + dry soil + water volume to reach $100 \%$ and $50 \%$ of soil WRC). Crop $^{+\circledR}$ biostimulant was applied at doses of 100 and $200 \mathrm{~mL} 100 \mathrm{~L}^{-1}$ (doses defined by the directions for use). Its application was performed on the leaves using a $\mathrm{CO}_{2}$-pressurized backpack sprayer, equipped with a 0.5 -meter-long wand containing two XR Teejet 110.02 nozzles, at pressure of $29 \mathrm{lb} \mathrm{in}^{-2}$ and application rate of $150 \mathrm{~L}$ ha ${ }^{-1}$. The application occurred in two distinct stages of crop development, periods that are considered of highest water demand; the first when tomato plants had nine or more true flowers, 69609 on BBCHscale (MEIER, 2001), and the second at the beginning of fruiting, 72702 on BBCH-scale (MEIER, 2001). After application of the Crop ${ }^{+\circledR}$ biostimulant, water stress $(50 \%$ of soil WRC) was induced for a period of 15 days.

Harvest was carried out when the fruits showed the characteristics of stage 5 (light red), according to a scale proposed by Paula (2012). After harvest, the fruits remained in the laboratory under controlled temperature $\left(15^{\circ} \mathrm{C}\right)$ and humidity $(85 \%)$ for shelf life evaluation. The values of total soluble solids (TSS), titratable acidity (TA) and $\mathrm{pH}$ were determined in samples of tomato pulp (around 200 grams), which were prepared with a Mondial Power 2 Black blender. Titratable acidity was determined by neutralization titrimetry with $\mathrm{NaOH}$ at $0.1 \mathrm{~mol} / \mathrm{L}$

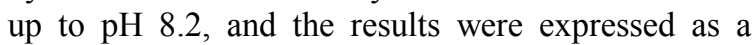
percentage. TSS were obtained through refraction with an Abbe WYA 2WA-J table refractometer, and the result found was expressed in ${ }^{\circ}$ Brix (MORETTI, 2006). The TSS/TA ratio is used to determine maturity in raw materials. The $\mathrm{pH}$ was determined by direct reading in homogenized pulp solution, using a portable digital $\mathrm{pH}$ meter with a $0.0-14$ scale, resolution of 0.1 , accuracy of $\leq \pm 0.03$ (OTONI et al., 2012).

Analysis of variance was conducted according to the mathematical model of a completely randomized design with three-factor arrangement. The experimental data were tested for normality (Shapiro-Wilk and Bartlett test to analyze the homogeneity of variances, with the help of the Action program) (ESTATCAMP, 2014). Subsequently, analysis of variance (ANOVA) and Scott-Knott test to group the means were performed at $5 \%$ probability level, using the statistical program Sisvar $^{\circledR} 5.3$ (FERREIRA, 2011).

\section{RESULTS AND DISCUSSION}

Tomato crop is sensitive to water deficit, especially during flowering (STEDUTO et al., 2012) and fruit formation (STEDUTO et al., 2012). In these periods, water stress causes disastrous effects on the plant, as these are periods of intense hormonal activity, and biochemical changes may occur in the plant (ENDRES et al., 2010). Under water deficit, the plant undergoes structural changes in the cell membrane due to protein denaturation. Water scarcity in plants leads to reduction of absorption, transport and percentage of water in fruits, favoring the concentration of acids (SIQUEIRA et al., 2009).

Biostimulants promote physiological changes that result in the growth and increase of yield and improvements in nutritional quality and shelf life of products (BATTACHARYYA et al., 2015; ANDERSON, 2009). Therefore, fruit quality is associated with parameters related to both qualitative characteristics of taste, external appearance and uniform color, and nutritional properties, namely soluble solids (SS) content, $\mathrm{pH}$, titratable acidity (TA), TSS/TA ratio (VIEIRA et al., 2014).

There was interaction between the factors soil water condition, application time and biostimulants in the treatments for $\mathrm{pH}$, titratable acidity (TA), total soluble solids (TSS) and TSS/TA ratio, at 18 days after harvest (DAH) (Table 1). By analyzing the $\mathrm{pH}$ values of tomato samples, it can be observed that plants treated with biostimulants and under both water conditions $(50 \%$ and $100 \%$ of soil WRC) showed an increase in $\mathrm{pH}$ values when compared to those in the control treatment.

In addition, the best efficiency of $\mathrm{Crop}^{+\circledR} 1 \mathrm{x}$ application occurred when the plant was at flowering and under $100 \%$ WRC water condition, with a $6.39 \%$ increase, when compared to the result of the control treatment. However, when the $\mathrm{Crop}^{+\circledR}$ dose was doubled $(2 x)$, the behavior of the product was different, obtaining the best result when applied at fruiting and with a water condition of $50 \%$ WRC. The other treatments with biostimulants did not differ statistically for the time of application or water condition imposed. 
M. PERIPOLLI et al.

Table 1. $\mathrm{pH}$ of tomato treated with biostimulants, at two times of application and two soil water conditions at 18 days after harvest. Santa Maria-RS, Brazil.

\begin{tabular}{|c|c|c|c|c|}
\hline \multirow{2}{*}{ Treatments } & \multicolumn{2}{|c|}{$50 \%$ WRC Water Condition } & \multicolumn{2}{|c|}{$100 \%$ WRC Water Condition } \\
\hline & Flowering & Fruiting & Flowering & Fruiting \\
\hline No treatment & $4.10 \mathrm{aA} \alpha$ & $4.10 \mathrm{aA} \alpha$ & $4.23 \mathrm{aB} \beta$ & $4.10 \mathrm{aA} \alpha$ \\
\hline Seed $^{+\circledR}$ & $4.47 \mathrm{cA} \alpha$ & $4.50 \mathrm{bA \alpha}$ & $4.40 \mathrm{bA} \alpha$ & $4.50 \mathrm{cA} \alpha$ \\
\hline $\operatorname{Seed}^{+\circledR}+\operatorname{Crop}^{+\circledR} 1 \mathrm{x}$ & $4.53 \mathrm{cA} \alpha$ & $4.50 \mathrm{bA \alpha}$ & $4.50 \mathrm{bA} \alpha$ & $4.50 \mathrm{cA} \alpha$ \\
\hline Seed $^{+\circledR}+$ Crop $^{+\circledR} 2 x$ & $4.50 \mathrm{cA} \beta$ & $4.43 \mathrm{bA} \alpha$ & $4.37 \mathrm{bA} \alpha$ & $4.40 \mathrm{cA} \alpha$ \\
\hline Crop $^{+\circledR} 1 \mathrm{x}$ & $4.40 \mathrm{cA} \alpha$ & $4.47 \mathrm{bA} \beta$ & $4.50 \mathrm{bB} \alpha$ & $4.30 \mathrm{bA} \alpha$ \\
\hline Crop $^{+\circledR} 2 \mathrm{x}$ & $4.23 \mathrm{bA} \alpha$ & $4.40 \mathrm{bB} \alpha$ & $4.43 \mathrm{bA} \beta$ & $4.43 \mathrm{cA} \alpha$ \\
\hline Mean & 4.43 & 4.42 & 4.45 & 4.42 \\
\hline CV (\%) & 1.8 & & & \\
\hline
\end{tabular}

Means not followed by the same letters differ significantly by Scott-Knott test at 5\% probability level; lowercase letters for comparisons in the column, uppercase letters for times of application and Greek letters for water conditions.

For tomato crop, the $\mathrm{pH}$ values should range between 4.2 and 4.5 , because this range prevents the proliferation of microorganisms and contributes to reducing losses in fruit postharvest (SILVA; GIORDANO, 2000). The $\mathrm{pH}$ is altered as a function of the fruit maturity stage and, according to Vieites, Daiuto and Fumes (2012), pH values decrease with the signs of maturation and increases with a substantial increase in ripening, due to the synthesis of organic acids. The present study showed favorable results, because the $\mathrm{pH}$ values remained below 4.5 in all evaluated periods. These values are similar to those mentioned by Sobreira et al. (2010) and Liu et al. (2010).

Through this study, it was observed that plants treated with biostimulants applied at flowering maintained $\mathrm{pH}$ levels equal to or higher than those associated with the application at fruiting. The use of biostimulants caused a reduction in the respiration rate of the fruits, thus increasing their shelf life, showing less activity and, consequently, reducing cell wall degradation and fruit softening.

As observed for $\mathrm{pH}$, the values of total soluble solids gradually increased up to a certain point, reaching a maximum value (at $18 \mathrm{DAH}$ ) and subsequently decreasing due to respiratory consumption. It can be observed in Table 2 that the biostimulants maintained higher mean values when compared to the control. The treatments Seed $^{+\circledR}+$ Crop $^{+\circledast} 2 \mathrm{x}$ and Crop ${ }^{+\circledast} 2 \mathrm{x}$ differed statistically from the others applied at flowering and under $50 \%$ of soil WRC. In addition, these same treatments had better results when the application time is compared, favored at flowering under $50 \%$ of soil WRC.

Table 2. Total soluble solids - TSS ( ${ }^{\circ}$ Brix) of tomato treated with biostimulants, at two times of application and two soil water conditions at 18 days after harvest. Santa Maria-RS, Brazil.

\begin{tabular}{|c|c|c|c|c|c|}
\hline & \multirow{2}{*}{ Treatments } & \multicolumn{2}{|c|}{$50 \%$ WRC Water Condition } & \multicolumn{2}{|c|}{$100 \%$ WRC Water Condition } \\
\hline & & Flowering & Fruiting & Flowering & Fruiting \\
\hline \multirow{6}{*}{$\begin{array}{l}1 \mathrm{x} \\
2 \mathrm{x}\end{array}$} & No treatment & $5.10 \mathrm{aA} \alpha$ & $5.23 \mathrm{aA} \alpha$ & $5.00 \mathrm{aA} \alpha$ & $5.10 \mathrm{aA} \alpha$ \\
\hline & Seed $^{+(\mathbb{B})}$ & $6.00 \mathrm{bA} \beta$ & $6.50 \mathrm{cB} \beta$ & $5.73 \mathrm{bA \alpha}$ & $6.27 \mathrm{aB} \alpha$ \\
\hline & Seed $^{+\circledR}+$ Crop $^{+(}$ & $6.10 \mathrm{bA} \alpha$ & $6.40 \mathrm{cB} \alpha$ & $6.40 \mathrm{cA} \beta$ & $6.37 \mathrm{bA \alpha}$ \\
\hline & Seed $^{+(B)}+$ Crop $^{+(B)}$ & $6.60 \mathrm{cB} \alpha$ & $6.13 \mathrm{bA} \alpha$ & $6.83 \mathrm{~dB} \beta$ & $6.20 \mathrm{bA} \alpha$ \\
\hline & $\operatorname{Crop}^{+(\mathbb{B})} 1 \mathrm{x}$ & $6.17 \mathrm{bA} \alpha$ & $6.20 \mathrm{bA} \alpha$ & $6.13 \mathrm{cA} \alpha$ & $6.20 \mathrm{bA} \alpha$ \\
\hline & $\operatorname{Crop}^{+\circledR} 2 \mathrm{x}$ & $6.77 \mathrm{cB} \beta$ & $6.47 \mathrm{cA} \alpha$ & $6.27 \mathrm{cA} \alpha$ & $6.80 \mathrm{cB} \beta$ \\
\hline & Mean & 6.12 & 6.15 & 6.06 & 5.96 \\
\hline & CV (\%) & 2.23 & & & \\
\hline
\end{tabular}

Means not followed by the same letters differ significantly by Scott-Knott test at 5\% probability level; lowercase letters for comparisons in the column, uppercase letters for times of application and Greek letters for water conditions.

It is observed that, under the water condition of $100 \%$ soil WRC, the results showed that the use of biostimulants increased the ${ }^{\circ}$ Brix of the tomato fruits, and the maximum value of TSS in this study occurred with $6.83{ }^{\circ}$ Brix in the treatment Seed ${ }^{+\circledR}+$ Crop. $_{-}^{+\circledR} 2 \mathrm{x}$ applied at fruiting. The increase in TSS content may be due to starch hydrolysis in ripening reactions, but a longer shelf life causes reduction in TSS content, due to the need for supplying the energy necessary to metabolic reactions (RINALDI et al., 2011). However, in the present study this deficiency did not occur, as it was met by the use of biostimulants, because they perform important function as senescence retardants (RAMOS et al., 2013).

The TSS content in tomato fruits may vary depending on the genetic characteristics of the plant, fertilization and especially abiotic factors, such as soil water condition (FERREIRA et al., 2010). Koetz et al. (2010) observed a decreasing linear 
relationship of TSS content with the increase in the irrigation water depths. These same authors recorded a value of $6.25^{\circ}$ Brix in industrial tomatoes for a water depth of $50 \%$ ETc, which is similar to the averages recorded in this experiment. Patanè et al. (2011) recorded values of $4.80{ }^{\circ}$ Brix for $100 \%$ ETc and 7.60 for $0 \%$ ETc.

Fratoni (2014) reported a linear increase of TSS content in tomato fruits, as a function of increasing doses of potassium $(\mathrm{K})$ in the nutrient solution. It is known that $\mathrm{K}$ is a nutrient that acts in the source-sink relationship, with regard to the transport of photoassimilates (MARSCHNER, 2011). Therefore, in the present study, the use of $\mathrm{Crop}^{+\circledR}$, which has doses of $\mathrm{K}$, is believed to have helped increase TSS.

A difference was observed in the TA of Santa Cruz Kada tomato (Table 3), with values ranging from $0.27 \%$ (Flowering, 50\% soil WRC) and $0.69 \%$ (Fruiting, $100 \%$ soil WRC). The TA of the tomato fruits was increasing as the dose of biostimulants increased, or the combination of biostimulants. The lowest values of TA were found under the condition of $50 \%$ soil WRC, in the treatments Seed $^{+\circledR}+$ Crop $+^{\circledR} 1 \mathrm{x}$; Seed $^{+\circledR}+$ Crop $^{+\circledR} 2 \mathrm{x}$; Crop $^{+\circledR} 1 \mathrm{x}$ and Crop $^{+\circledR}$ $2 \mathrm{x}$, as a function of the nutrients present in the composition of the $\mathrm{Crop}^{+\otimes}$ biostimulant. Fruits belonging to the control treatment had higher acidity when compared to the other treatments.

Table 3. Titratable acidity - TA (\%) of tomato treated with biostimulants, at two times of application and two soil water conditions at 18 days after harvest. Santa Maria-RS, Brazil.

\begin{tabular}{|c|c|c|c|c|c|}
\hline & \multirow{2}{*}{ Treatments } & \multicolumn{2}{|c|}{$50 \%$ WRC Water Condition } & \multicolumn{2}{|c|}{$100 \%$ WRC Water Condition } \\
\hline & & Flowering & Fruiting & Flowering & Fruiting \\
\hline \multirow{6}{*}{$\begin{array}{l}1 x \\
2 x\end{array}$} & No treatment & $0.67 \mathrm{cA} \alpha$ & $0.66 \mathrm{cA} \alpha$ & $0.69 \mathrm{dA} \alpha$ & $0.65 \mathrm{dA} \alpha$ \\
\hline & Seed $^{+\circledR}$ & $0.62 \mathrm{cA} \alpha$ & $0.55 \mathrm{bA} \alpha$ & $0.57 \mathrm{cA} \alpha$ & $0.57 \mathrm{cA} \alpha$ \\
\hline & $\operatorname{Seed}^{+(B)}+$ Crop $^{+(}$ & $0.48 \mathrm{bB} \alpha$ & $0.46 \mathrm{aA} \alpha$ & $0.51 \mathrm{bA} \alpha$ & $0.52 \mathrm{cA} \alpha$ \\
\hline & $\operatorname{Seed}^{+\circledast}+$ Crop $^{+\circledast}$ & $0.32 \mathrm{aA} \alpha$ & $0.45 \mathrm{aB} \alpha$ & $0.42 \mathrm{aA} \beta$ & $0.46 \mathrm{bA} \alpha$ \\
\hline & Crop $^{+(} 1 \mathrm{x}$ & $0.36 \mathrm{aA} \alpha$ & $0.44 \mathrm{aB} \alpha$ & $0.43 \mathrm{aA} \alpha$ & $0.37 \mathrm{aA} \alpha$ \\
\hline & Crop $^{+(} 2 \mathrm{x}$ & $0.27 \mathrm{aA} \alpha$ & $0.38 \mathrm{aB} \alpha$ & $0.37 \mathrm{aA} \beta$ & $0.38 \mathrm{aA} \alpha$ \\
\hline & Mean & 0.45 & 0.49 & 0.50 & 0.49 \\
\hline & CV (\%) & 9.06 & & & \\
\hline
\end{tabular}

Means not followed by the same letters differ significantly by Scott-Knott test at 5\% probability level; lowercase letters for comparisons in the column, uppercase letters for times of application and Greek letters for water conditions.

TA varied along the evaluated period, reaching a $0.40 \%$ difference when compared to the control. The use of biostimulant promoted a significant increase in the variables $\mathrm{pH}$, TSS and TA. The contents of TA (greater than $0.30 \%$ ) and TSS (between 5 and $7{ }^{\circ}$ Brix) found in this study are within the values considered adequate for quality, because they had mean values of $0.49 \%$ and $5.55 \%$, respectively.

As the fruit ripens, there is a reduction in TA due to the loss of citric acid (ANTHON; LESTRANGE; BARRETT, 2011), as observed in the present study. Heine et al. (2015) found values around $0.37 \%$. Santos et al. (2018) found mean values of $0.3 \%$ for the Santa Cruz variety, close to those observed in the present study when the biostimulants Seed ${ }^{+\circledR}$ and Crop ${ }^{+\circledR}$ were used. Martins et al. (2013) observed that, for watermelon, biostimulants influenced the soluble solids content and titratable acidity of the fruits, as observed in the present study.

There were high values (above 10) in the TSS/TA ratio (Table 4), indicating an excellent combination of sugar and acid, which are correlated with a mild flavor, while low values are correlated with acidic and worse fruit flavor. In this experiment this ratio ranged from 5.28 to 25.88 , indicating that it is a great product for processing, as well as fresh consumption.

TSS/TA values were high in all biostimulant treatments compared to the control treatment. The highest mean values for TSS/TA ratio at 18 days were found in treatments with biostimulant application, while the lowest value was found in the control treatment. It is observed that, at flowering under $100 \%$ soil WRC, the difference reached $50 \%$ in a comparison between the control treatment with the treatments Seed $^{+\circledR}+\operatorname{Crop}^{+\circledR} 2 \mathrm{x}$, Crop $^{+\circledR} 1 \mathrm{x}$ and Crop $^{+\circledR} 2 \mathrm{x}$.

The TSS/TA ratio showed better results for the treatments Seed $^{+\circledR}+\operatorname{Crop}^{+\circledR} 2 \mathrm{x}$, Crop $^{+\circledR} 1 \mathrm{x}$ and Crop $^{+\circledR} 2 \mathrm{x}$ under $50 \%$ soil WRC, when the moments of application are compared, with flowering standing out. Thus, it is concluded that biostimulants can help in the postharvest of fruits for a period of 18 days without compromising their quality. In addition, it can be concluded that the use of biostimulants was favored when they were applied at flowering, under the two water conditions tested.

The TSS/TA ratio is used to describe fruit maturation; the higher the coefficient, the greater the soluble solids content and consequently the sweeter 
the fruit (ARAÚJO et al., 2014). According to Lima et al. (2011), high-quality tomato fruits are characterized by containing more than 0.32 TTA, 3 ${ }^{\circ}$ Brix of TSS and a TSS/TTA ratio greater than 10 .
The TSS, TTA and TSS/TTA ratio found in the present study are within the limits established by these authors.

Table 4. Total soluble solids - TSS/Total titratable acidity - TTA ratio (\%) of tomato treated with biostimulants, at two times of applications and two soil water conditions at 18 days after harvest. Santa Maria-RS, Brazil.

\begin{tabular}{|c|c|c|c|c|c|}
\hline & \multirow{2}{*}{ Treatments } & \multicolumn{2}{|c|}{$50 \%$ WRC Water Condition } & \multicolumn{2}{|c|}{$100 \%$ WRC Water Condition } \\
\hline & & Flowering & Fruiting & Flowering & Fruiting \\
\hline \multirow{6}{*}{$\begin{array}{l}1 \mathrm{x} \\
2 \mathrm{x}\end{array}$} & No treatment & $7.70 \mathrm{aA} \alpha$ & $7.90 \mathrm{aA} \alpha$ & $7.30 \mathrm{aA} \alpha$ & $7.96 \mathrm{aA} \alpha$ \\
\hline & \multirow{2}{*}{$\begin{array}{l}\text { Seed }^{+(\mathbb{B}} \\
\text { Seed }^{+(}+\text {Crop }^{+\circledast}\end{array}$} & $9.79 \mathrm{aA} \alpha$ & $11.85 \mathrm{bA} \alpha$ & $10.15 \mathrm{aA} \alpha$ & $11.02 \mathrm{bA} \alpha$ \\
\hline & & $12.65 \mathrm{bA} \alpha$ & $14.04 \mathrm{bA} \alpha$ & $12.80 \mathrm{bA} \alpha$ & $12.31 \mathrm{bA} \alpha$ \\
\hline & Seed $^{+\circledR}+$ Crop $^{+(\mathbb{B}}$ & $20.77 \mathrm{~dB} \beta$ & $13.69 \mathrm{bA} \alpha$ & $16.51 \mathrm{cA} \alpha$ & $13.40 \mathrm{bA} \alpha$ \\
\hline & Crop $^{+\circledR} 1 \mathrm{x}$ & $17.04 \mathrm{cB} \alpha$ & $14.00 \mathrm{bA} \alpha$ & $14.48 \mathrm{bA} \alpha$ & $16.56 \mathrm{cA} \alpha$ \\
\hline & Crop $^{+(} 2 x$ & $25.88 \mathrm{eB} \beta$ & $17.02 \mathrm{cA} \alpha$ & $17.13 \mathrm{cA} \alpha$ & $18.16 \mathrm{cA} \alpha$ \\
\hline & Mean & 15.64 & 13.08 & 13.06 & 13.23 \\
\hline & CV (\%) & 12.45 & & & \\
\hline
\end{tabular}

Means not followed by the same letters differ significantly by Scott-Knott test at 5\% probability level; lowercase letters for comparisons in the column, uppercase letters for times of application and Greek letters for water conditions.

\section{CONCLUSIONS}

Water stress affects the quality of tomato fruits, so the applications of the biostimulants Seed ${ }^{+\circledR}$ and $\mathrm{Crop}^{+\circledR}$ were able to reverse the damage caused by water stress, resulting in an improvement in the quality of tomato fruits.

The use of Seed ${ }^{+\circledR}$ and Crop $\left.{ }^{+(}\right)$biostimulants maintains the useful life of tomato fruits until 18 days after harvest, with no loss of quality.

\section{REFERENCES}

ALBACETE, A. A.; MARTÍNEZ-ANDÚJAR, C.; PÉREZ-ALFOCEA, F. Regulação hormonal e metabólica das relações fonte-imundície sob salinidade e seca: da sobrevivência das plantas à estabilidade do rendimento das culturas. Biotechnology Advances, 32: 12-30, 2014.

ANDERSON, G. Seawees extract shows improved fruit quality at AcLaren Vale vineyard trial. Astralian e New Zealand Grapegrower e Winemaker, 548: 17-22, 2009.

ANTHON, G. E.; LESTRANGE, M.; BARRETT, D. M. Changes in $\mathrm{pH}$, acids, sugars and other quality parameters during extended vine holding of ripe 51 processing tomatoes. Journal of the Science of Food and Agriculture, 91: 1175-1181, 2011.

ARAUJO, J. C Physico-chemical and sensory parameters of tomato cultivars grown in organic systems. Horticultura Brasileira, 32: 205- 209, 2014.

BATTACHARYYA, D. et al. Seaweed extracts as biostimulants in horticulture. Scientia Horticulturae, 196: 39-48, 2015.

BRITO JUNIOR, F. P. Produção de tomate Solanum lycopersicum L.) reutilizando substratos sob cultivo protegido no município de IrandubaAM. 2012. 60 f. Dissertação (Mestrado em Fitotecnia: Área de Concentração Produção Vegetal) - Universidade Federal do Amazonas, Manaus, 2012.

BULGARI, R. et al. Biostimulants and crop responses: a review. Biological Agriculture \& Horticulture, 31: 1-17, 2015.

CALVO, P.; NELSON, L.; KLOEPPER, J. W. Agricultural uses of plant biostimulants. Plant Soil, 383: 3-41, 2014

DU JARDIN, P. Plant biostimulants: definition, concept, main categories and regulation. Scientia Horticulturae, 196: 3-14, 2015.

ENDRES, L. et al. Gas exchange alteration caused by water deficit during the bean reproductive stage. Revista Brasileira de Engenharia Agrícola e Ambiental, 14: 11-16, 2010.

ESTATCAMP. Software Action. Estatcamp Consultoria em estatística e qualidade, São Carlos, SP, 2014. Available at: http:// www.portalaction.com.br. Access on: Dec. 22, 2018.

FERREIRA, D. F. Sisvar: a computer statistical analysis system. Ciência e Agrotecnologia, 35: 1039-1042, 2011.

FERREIRA, S. M. R. et al. Qualidade do tomate de 
mesa cultivado nos sistemas convencional e orgânico. Ciência e Tecnologia de Alimentos, 30: 224-230, 2010.

FERREIRA, S. M. R. et al. Qualidade pós colheita do tomate de mesa convencional e orgânico. Ciência e Tecnologia de Alimentos, 30: 858-869, 2012.

FRATONI, M. M. J. Nutrição potássica em tomateiro fertirrigado e cultivado em vasos contendo areia. 2014. 53 f. Dissertação (Mestrado em Fitotecnia: Área de Concentração em Propagação, manejo e melhoramento genético de plantas ornamentais e frutíferas) - Universidade Estadual de Londrina, Londrina, 2014.

GOLLDACK, D. et al. Tolerância à seca e estresse salino em plantas: desvendar as redes de sinalização. Fronteiras em Plant Science, 5: 151, 2014.

HEINE, M. J. A. et al. Número de haste e espaçamento na produção e qualidade do tomate. Revista Scientia Plena, 11: 1-7, 2015.

HELDWEIN, A. B.; BURIOL, G. A.; STRECK, N. A. O clima de Santa Maria. Ciência e Ambiente, 38: 43-58, 2009.

INSTITUTO BRASILEIRO DE GEOGRAFIA E ESTATÍSTICA - IBGE. Levantamento sistemáticoÝa produção Agrícola: Pesquisa mensal de previsão e acompanhamento das safras agrícolas no ano civil. Disponível em: <https:// biblioteca.ibge.gov.br/visualizacao/periodicos/2415/ epag_2019_jan.pdf $>$. Acesso em: 09 mar. 2019.

KOETZ, M. Caracterização agronômica e ${ }^{\circ}$ Brix em frutos de tomate industrial sob irrigação por gotejamento no sudoeste de goiás. Revista Brasileira de Agricultura Irrigada, 4: 14-22, 2010.

LIMA, A. A. et al. Concentração foliar de nutrientes e produtividade do tomateiro cultivado sob diferentes substratos e doses de ácidos húmicos. Horticultura Brasileira, 29: 63-69, 2011.

LIU, F. et al. Changes of tomato powder qualities during storage. Powder Technology, 204: 159-166, 2010 .

MARSCHNER, P. Marschner's mineral nutrition of higher plants. 3rd ed. Waltham: Academic Press, 2011. $672 \mathrm{p}$.

MARTINS, J. C. P. et al. Caracteristicas póscolheita dos frutos de cultivares de melancia, submetidas à aplicação de bioestimulante. Revista Caatinga, 26: 18-24, 2013.
MEIER, U. Growth stages of mono-and dicotyledonous plants - BBCH. 2. ed. Berlin: German Federal Biological Research Centre for Agriculture and Forestry, 131, 2001.

MORETTI, C. L. Protocolos de Avaliação da Qualidade Química e Física de Tomate. Comunicado Técnico 32. Disponível em: $<$ https:// www.infoteca.cnptia.embrapa.br/infoteca/handle/ doc/779806> . Acesso em: 22 fev. 2019.

MOZDZEN, K. et al. Effect of drought stress induced by mannitol on physiological parameters of maize (Zea mays L.) seedlings and plants. The Journal of Microbiology, Biotechnology and Food Sciences, 4: 86-91, 2015.

NASIR, M. U. et al. Tomato processing, lycopene and health benefits: A review. Science Letters, 3: 15,2015 .

OTONI, B. S. et al. Produção de híbridos de tomateiro cultivados sob diferentes porcentagens de sombreamento. Revista Ceres, 59: 816-825, 2012

PATANE, C. Leaf area index, leaf transpiration and stomatal conductance as affected by soil water deficit and VPD in processing tomato in semi arid Mediterranean climate. Journal of Agronomy \& Crop Science, 197: 165-176, 2011.

PAULA, J. T. Qualidade pós-colheita de genótipos de tomateiro colhidos em diferentes estádios de maturação. 2012. 93 f. Dissertação (Mestardo em Fitotecnia: Área de Concentração Produção Vegetal) - Universidade Estadual do Centro-Oeste, Guarapuava, 2012.

RAMOS, A. R. P. et al. Qualidade de frutos de tomate 'Giuliana' tratados com produtos de efeitos fisiológicos. Semina: Ciências Agrárias, 34: 3543 3552, 2013

RINALDI, M. M. Avaliação da vida útil e de embalagens para tomate de mesa em diferentes condições de armazenamento. Boletim CEPPA, 29: 305-316, 2011.

SANTOS, J. M. S. M. et al. Qualidade pós-colheita de duas variedades de tomates. Revista Craibeiras de Agroecologia, 3: e6550, 2018.

SCHWAB, N. T. Disponibilidade hídrica no cultivo de cravina em vasos com substrato de cinzas de casca de arroz. 2011. 82 f. Dissertação (Mestrado em Engenharia Agrícola: Área de Concentração Engenharia de água e solo) Universidade Federal de Santa Maria, Santa Maria, 2011. 
SILVA, J. B. C.; GIORDANO, L. B. Tomate para processamento industrial. EMBRAPA/Hortaliças, $168,2000$.

SIQUEIRA, C. W.; FARIA, A. L. Qualidade de frutos de melão amarelo cultivado em casa de vegetação sob diferentes lâminas de irrigação. Ciência e Agrotecnologia, 33: 1041-1046, 2009.

SOBREIRA, F. M. et al. Qualidade de sabor de tomates dos tipos salada e cereja e sua relação com caracteres morfoagronômicos dos frutos. Ciência e Agrotecnologia, 34: 1015-1023, 2010.

STAJCIC', S. et al. Tomato waste: Carotenoids content, antioxidant and cell growth activities. Food Chemistry, 172: 225-232, 2015.

STEDUTO, P. et al. Crop yield response to water. Food And Agriculture Organization of the United Nations, 505, 2012.

VAN OOSTEN, M. J. et al. The role of biostimulants and bioeffectors as alleviators of abiotic stress in crop plants. Chemical and Biological Technologies in Agriculture, 4: 5, 2017.

VIEIRA, D. A. Qualidade física e química de minitomates Sweet Grape produzidos em cultivo orgânico e convencional. Revista Verde de AgroecologiaP Desenvolvimento Sustentável, 9: 100-108, 2014.

VIEITES, R. L.; DAIUTO, É. R.; FUMES, J. G. F. Capacidade antioxidante e qualidade pós-colheita de abacate 'Fuerte'. Revista Brasileira de Fruticultura, 34: 336-348, 2012. 